\title{
EFFECTS OF VIBRO-COMPOSER AND PRELOADING ON THE ELASTIC MODULUS OF SOIL
}

\author{
by Dr. SHIZUO YAMAMOTO* Member of A.I.J. \\ TAKASHI SEKI** \\ NOBUAKI SUZUKI*** "
}

\section{Introduction}

It is necessary to know the elastic modulus of the soil for the dynamical design of structures considering the effects of the soil. If the elastic modulus of the soil can be made clear in relation to the physical property of the soil or the some coefficient representing the soil condition such as $N$ value, void ratio, strength of the soil etc., the dynamical design of structure considering soil will become more easily. In this report the elastic modulus of the soil is evaluated from the forced vibration test of foundations and the measurement of the shear wave velocity, and is studied in relation with the physical property of the soil and the some coefficient representing the soil condition. Also, the effects of the vibro-composer and preloading for elastic modulus of soil are studied.

\section{Soil Condition}

The locality and the soil conditions of test ground are shown in Fig. 1 and Fig. 2. The soil stabilization method was performed to strengthen the $F$ and $S$ stratum and to prevent differential settlement, i.e., sand-drain method was performed

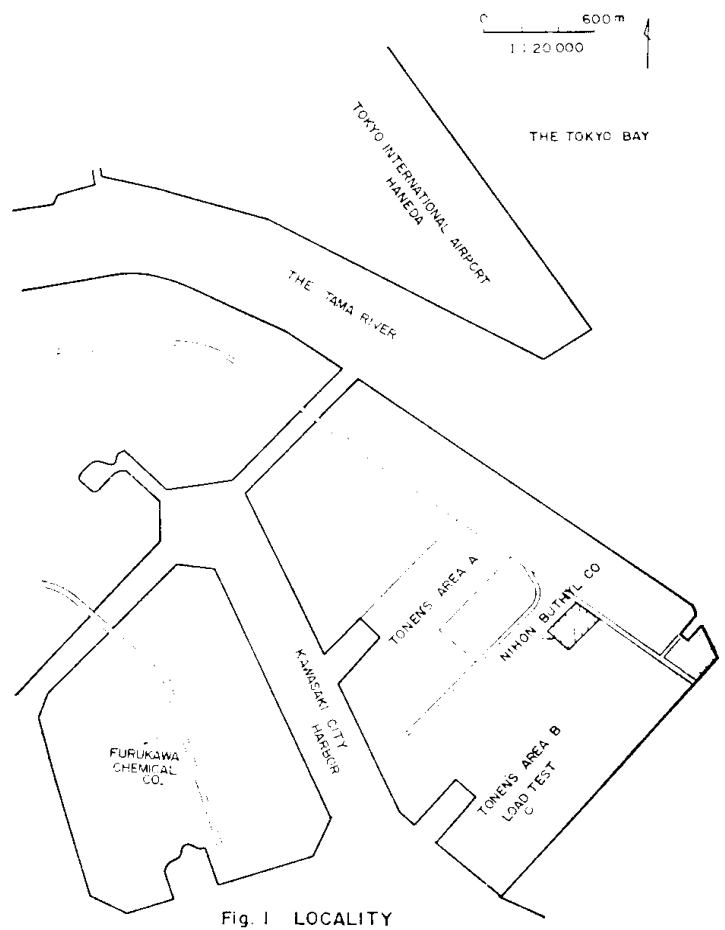

Fig. 1 Locality of Kawasaki Factory Site Nihon Buthyl Co., Ltd.

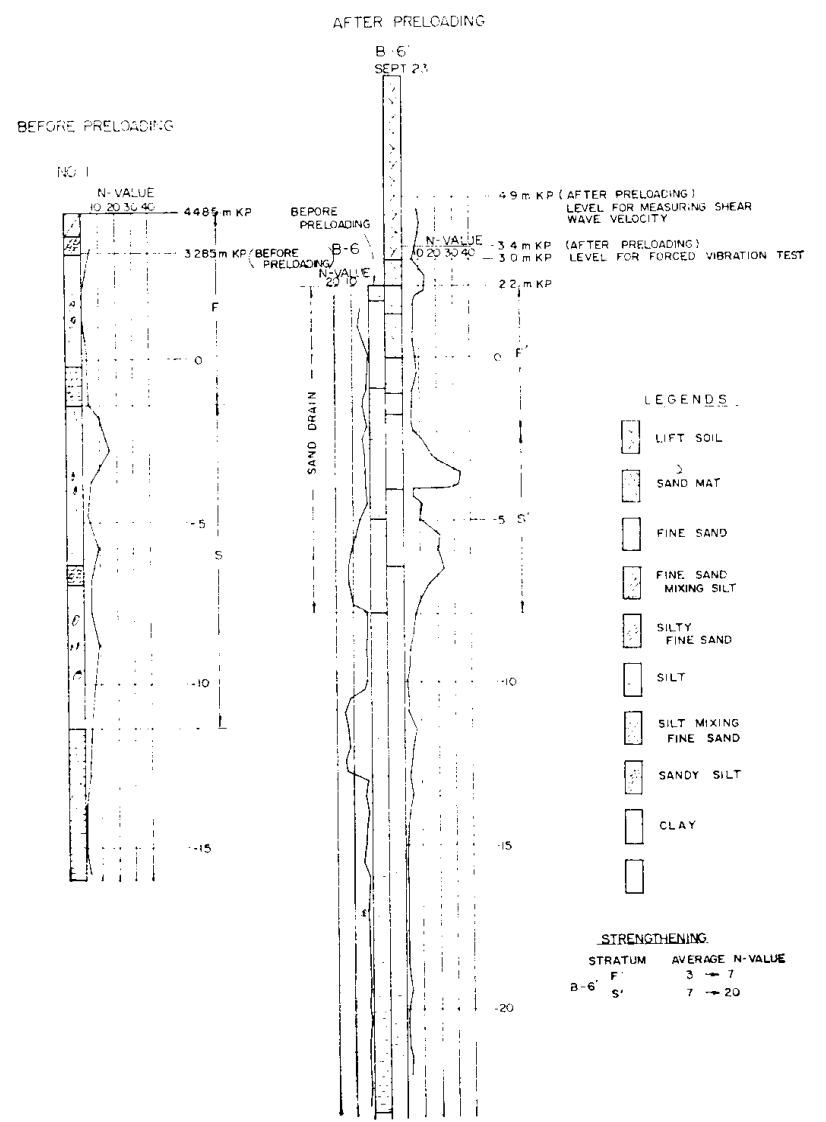

Fig. 2 Boring Log

* Chiyoda Chemical Engineering \& Construction Co.. Ltd. Research Department Staff Engineer

** Research Engineer 


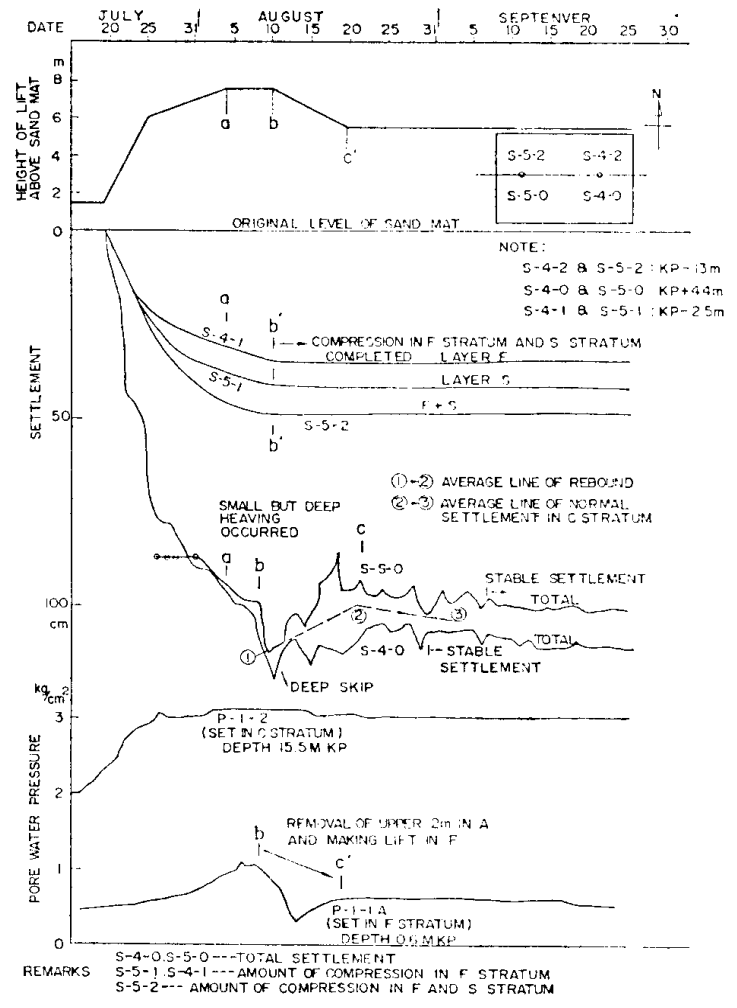

Fig. 3 Settlement and Rore Pressure
Table 1 Results of Soil Test

\begin{tabular}{|c|c|c|c|c|c|}
\hline \multirow{9}{*}{ 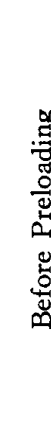 } & & & $\begin{array}{l}\text { F-Stratum } \\
\text { Boring } \\
\text { No. } 1 \\
5.00 \sim 5.80\end{array}$ & $\begin{array}{c}\text { S-Stratum } \\
\text { Boring } \\
\text { No. } 4 \\
10.00 \sim 10.60\end{array}$ & $\begin{array}{c}\text { CI-Stratum } \\
\text { Boring } \\
\text { No. } 2 \\
17.00 \sim 17.80\end{array}$ \\
\hline & $w$ & $\%$ & 45.9 & 39.0 & 57.5 \\
\hline & $G$ & & 2.72 & 2.70 & 2.71 \\
\hline & $r_{t}$ & $\mathrm{~g} / \mathrm{cm}^{3}$ & 1.93 & 1.80 & 1.24 \\
\hline & $r_{d}$ & $\mathrm{~g} / \mathrm{cm}^{3}$ & 1.18 & 1.29 & 1.04 \\
\hline & $e$ & & 1.29 & 0.90 & 1.60 \\
\hline & $q_{v}$ & $\mathrm{~kg} / \mathrm{cm}^{2}$ & $0.405 \sim 0.514$ & $0.285 \sim 0.710$ & $0.890 \sim 1.265$ \\
\hline & $c$ & $\mathrm{~kg} / \mathrm{cm}^{2}$ & 0.00 & 0.45 & 0.00 \\
\hline & $\phi$ & & $23^{\circ} 00^{\prime}$ & $27^{\circ} 10^{\prime}$ & $24^{\circ} 30^{\prime}$ \\
\hline \multirow{9}{*}{ 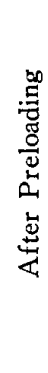 } & & & $\begin{array}{c}\text { B-6' } \\
6.00 \sim 6.30\end{array}$ & $\begin{array}{c}\text { B-6 } \\
11.00 \sim 13.30\end{array}$ & $\begin{array}{c}\mathrm{B}-6^{\prime} \\
14.00 \sim 15.30\end{array}$ \\
\hline & $w$ & $\%$ & 33.8 & 29.3 & 27.2 \\
\hline & $G$ & & 2.72 & 2.69 & 2.70 \\
\hline & $r_{t}$ & $\mathrm{~g} / \mathrm{cm}^{3}$ & 1.89 & 1.82 & 2.03 \\
\hline & $r_{d}$ & $\mathrm{~g} / \mathrm{cm}^{3}$ & 1.41 & 1.33 & 1.60 \\
\hline & $e$ & & 0.93 & 1.08 & 0.69 \\
\hline & $q_{u}$ & $\mathrm{~kg} / \mathrm{cm}^{2}$ & & & \\
\hline & $c$ & $\mathrm{~kg} / \mathrm{cm}^{2}$ & & & \\
\hline & $\phi$ & & & & \\
\hline
\end{tabular}

for $F$ and $S$ stratum with preloading. The timeload curve for preloading and time-settlement curves are shown in Fig. 3. The boring logs

before preloading and after preloading are compareb in Fig. 2. As a result of soil stabilization method, $N$ value was strengthened to 7 from 3 at $F$ stratum and 20 from 7 at $S$ stratum. The laboratory test results of soil are shown in Table 1 .

\section{Experimental Method}

The vibration tests of model foundations and the measurement of $S$ wave velocity were performed at the ground before and after preloading in order to know the contributions of sand-drains and preloading to increasing the elastic modulus of the soil. The foundations for forced vibration test are shown in Fig. 4-(a) and (b). The ground levels for each test are shown in Fig. 2.

The forced vibration test of foundation was performed, oscillating the foundations by the vibrator installed on it, varying the exciting frequency step by step, and the amplitudes at the several points of the foundation were measured by vibrometer. Then, resonance curves and vibrating modes of the foundation at resonance were obtained. The center of exciting force is located at $38 \mathrm{~cm}$ high from the surface of test foundation. The standard measuring points for two kinds of oscillating direction, i.e. vertical and horizontal direction to obtain the resonant curves are shown in Fig. 4-(a) and (b). In the case of horizontal excitation, the modes of sliding and rocking were coupled, since the center of

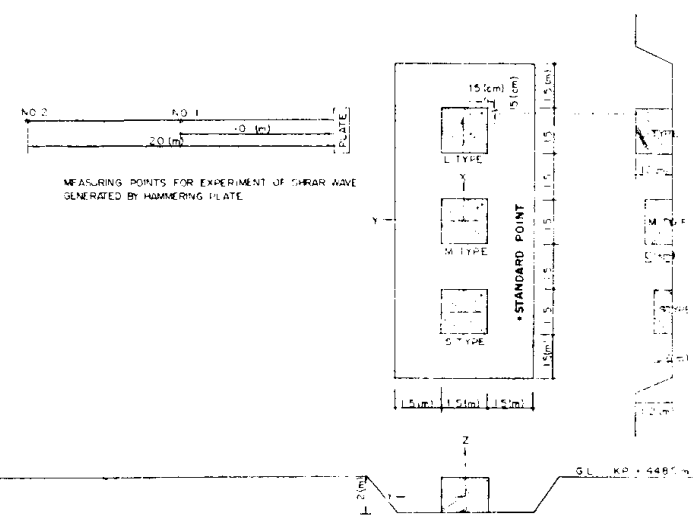

Fig. 4-(a) Test Foundations and Arrangement of Measuring Points before Preloading

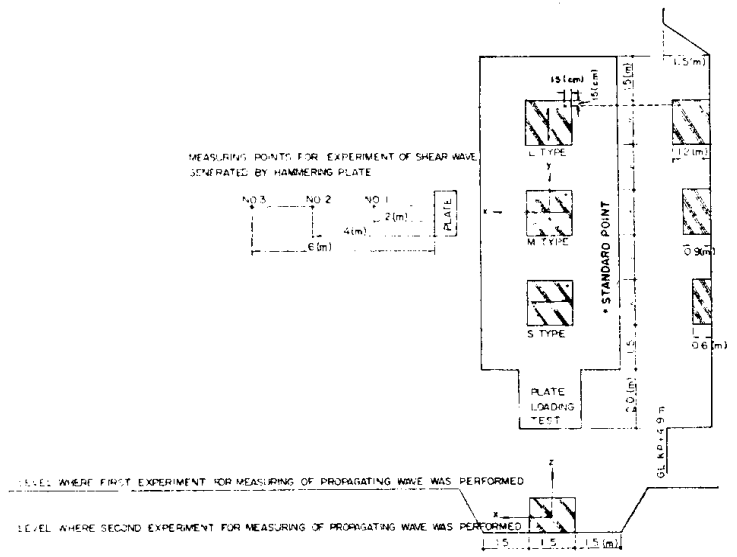

Fig. 4-(b) Test Foundations and Arrangement of Measuring Points after Preloading 
exciting force didnot coincide with the center of gravity of test foundations. "VERTICAL" and "HORIZONTAL" in the following figures and tables show the direction of excitation, respectively. This experiments were repeated several times, according to several magnitude of eccentric moment of the vibrator. The dynamical $k$-values and the critical damping ratio from these data were obtained.

The measurement of $S$-wave velocity was performed as follows, i.e., a wooden plate, $1 \mathrm{~m}$ long, $40 \mathrm{~cm}$ wide and $3 \mathrm{~cm}$ thick, was place on the ground, contacting smoothly the plate and the ground surface, by cement powder scattered on the surface of ground, and then $\mathrm{SH}$-waves were generated by hitting either end of the wooden plate horizontally which weighted by several persons using a wooden sledge hammer. The seismometers were arranged on the ground surface as shown in Fig. 4-(a) and (b). Then, the shear wave velocity was obtained as phase velocity from the the time-lag-distance curve.

\section{Experimental Results and Consideration}

\section{3-1 Resonance Curve and Subgrade Reaction}

The resonance curves at the top of foundation obtained from forced vibration test of foundations are shown in Fig. 5 thru Fig. 10. The test results for the dynamical $k$-value and the critical damping ratio are shown in Table 2 and 3 . From the resonance curves, it is observed that the resonant frequency becomes low according to increasing the amplitude. Fig. 11 shows the relationship between resonant frequency and resonant amplitude. Fig. 12 shows the relationship between dynamical $k$-value evaluated from coupled vibration of horizontal and rotation and resonant amplitude. The under linear characteristic of stress-strain is observed more clearly from these figures. In Fig. 11 and 12 the test

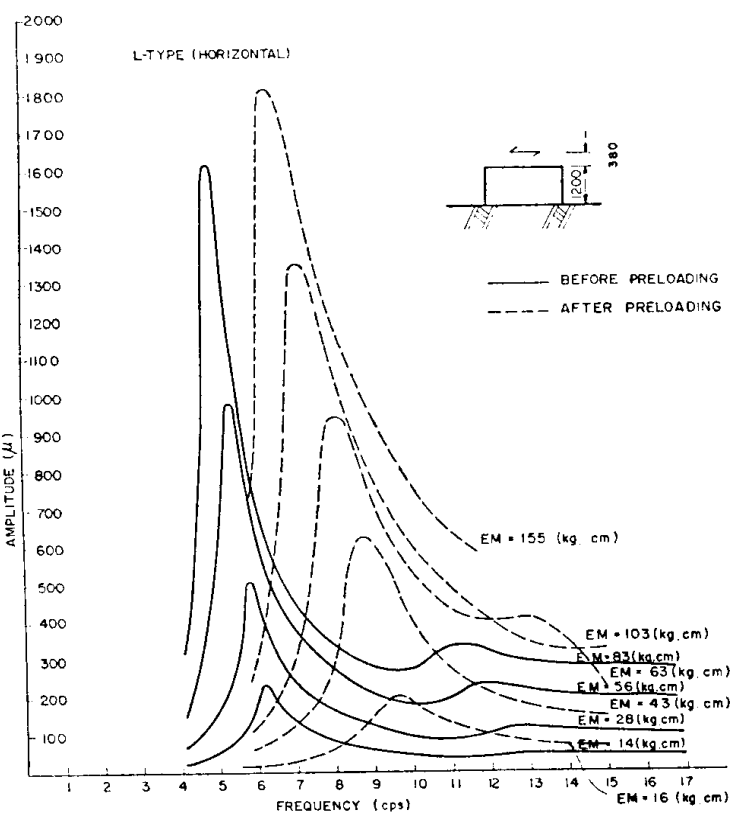

Fig. 5 Resonance Curves

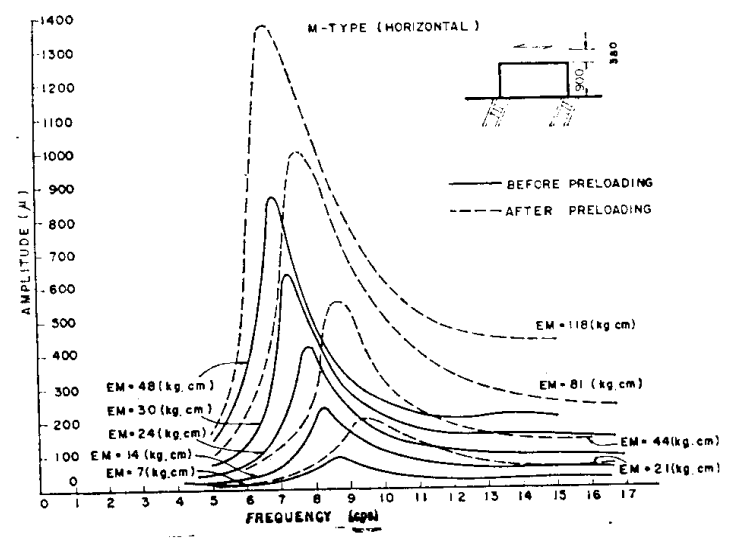

Fig. 6 Resonance Curves results before preloading and after preloading are plotted on the same figures. It is observed from these figures that after preloading the natural frequency and dynamical $k-$

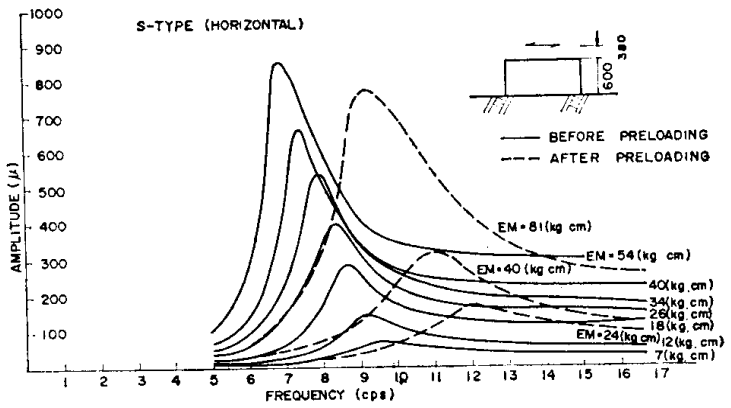

Fig. 7 Resonance Curves

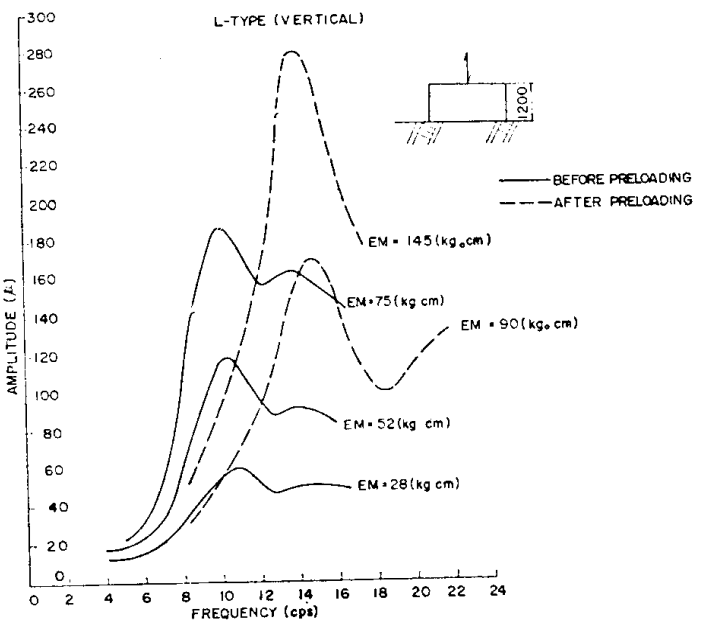

Fig. 8 Resonance Curves 


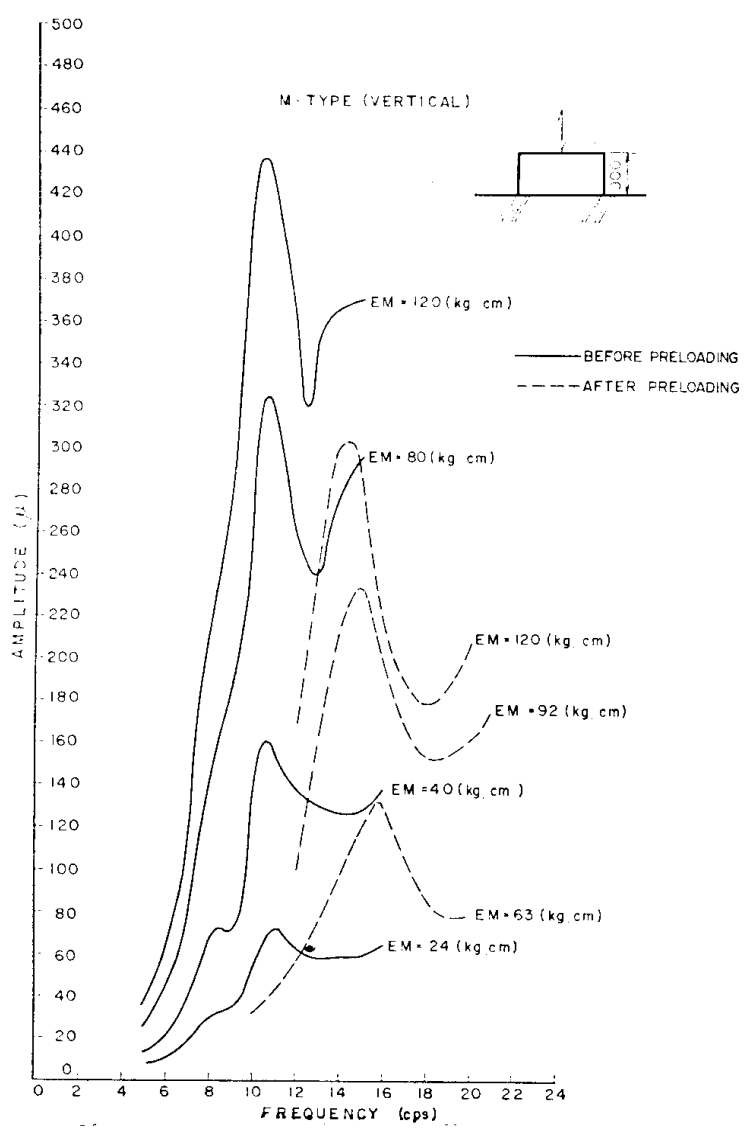

Fig. 9 Resonance Curves

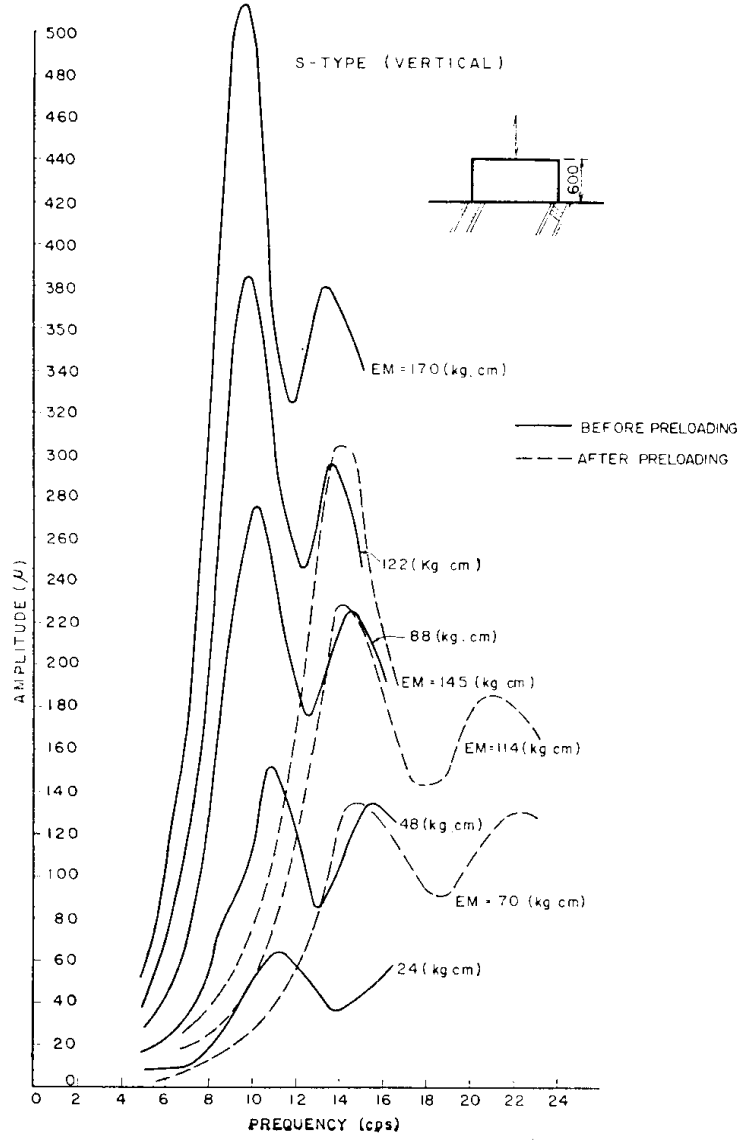

Fig. 10 Resonance Curves

Table 2 Test Results of Dynamic Coefficient of Subgrade Reaction and Critical Damping Ratio (Before Preloading)

\begin{tabular}{|c|c|c|c|c|c|c|c|c|}
\hline \multirow{2}{*}{$\begin{array}{c}\text { Type of } \\
\text { Concrete } \\
\text { Block }\end{array}$} & \multirow{2}{*}{$\begin{array}{l}\text { Test } \\
\text { No. }\end{array}$} & \multirow{2}{*}{$\begin{array}{l}\text { Excited } \\
\text { Direction }\end{array}$} & \multirow{2}{*}{$\begin{array}{l}\text { Eccentric } \\
\text { Moment } \\
(\mathrm{kg} \cdot \mathrm{cm})\end{array}$} & \multicolumn{2}{|c|}{ Resonant Frequency } & \multicolumn{2}{|c|}{$\begin{array}{c}\text { Dynamic Coefficient of } \\
\text { Subgrade Reaction }\end{array}$} & \multirow{2}{*}{$\begin{array}{c}\text { Critical } \\
\text { Damping } \\
\text { Ratio } \\
h\end{array}$} \\
\hline & & & & $\underset{(\mathrm{cps})}{f}$ & $(\mathrm{rad} / \mathrm{sec})^{2}$ & $\begin{array}{c}k_{h} \\
\left(\mathrm{~kg} / \mathrm{cm}^{3}\right)\end{array}$ & $\begin{array}{c}k_{v} \\
\left(\mathrm{~kg} / \mathrm{cm}^{3}\right)\end{array}$ & \\
\hline \multirow{7}{*}{ L Type } & 1 & \multirow{4}{*}{ Horizontal } & 14 & 6.17 & 1,500 & 1.01 & 3.58 & 0.0605 \\
\hline & 2 & & 28 & 5.83 & 1,345 & 0.97 & 3.11 & 0.06 \\
\hline & 3 & & 56 & 5.42 & 1,160 & 0.68 & 2.82 & 0.070 \\
\hline & 4 & & 83 & 4.75 & 892 & 0.55 & 2.08 & 0.073 \\
\hline & 5 & \multirow{3}{*}{ Vertical } & 28 & 11.33 & 5,090 & & 1.68 & \\
\hline & 6 & & 52 & 10.42 & 4,290 & & 1.42 & \\
\hline & 7 & & 75 & & & & & \\
\hline \multirow{10}{*}{ M Trpe } & 8 & \multirow{5}{*}{ Horizontal } & 7 & 8.75 & 3,030 & 1.23 & 4.93 & 0.069 \\
\hline & 9 & & 14 & 8.33 & 2,740 & 1.04 & 4.95 & 0.0697 \\
\hline & 10 & & 24 & 7.83 & 2,425 & 1.13 & 3.45 & 0.0705 \\
\hline & 11 & & 34 & 7.18 & 2,030 & 0.91 & 3.00 & 0.071 \\
\hline & 12 & & 48 & 6.67 & 1,755 & 0.34 & 2.44 & 0.081 \\
\hline & 13 & \multirow{5}{*}{ Vertical } & 24 & 11.00 & 4,780 & & 1.23 & \\
\hline & 14 & & 48 & 10.83 & 4,650 & & 1.19 & \\
\hline & 15 & & 88 & 10.42 & 4,290 & & 1.10 & \\
\hline & 16 & & 122 & 9.58 & 3,630 & & 0.93 & \\
\hline & 17 & & 170 & 9.58 & 3,630 & & 0.93 & \\
\hline \multirow{11}{*}{ S Type } & 18 & \multirow{7}{*}{ Horizontal } & 7 & 9.67 & 3,700 & 0.98 & 3.20 & 0.098 \\
\hline & 19 & & 12 & 9.50 & 3,570 & 0.89 & 3.43 & 0.0925 \\
\hline & 20 & & 18 & 8.75 & 3,030 & 0.80 & 2.66 & 0.087 \\
\hline & 21 & & 26 & 8.33 & 2,740 & 0.83 & 2.04 & 0.089 \\
\hline & 22 & & 34 & 7.83 & 2,425 & 0.64 & 2.13 & 0.0855 \\
\hline & 23 & & 40 & 7.50 & 2,230 & 0.56 & 2.14 & 0.088 \\
\hline & 24 & & 45 & 6.67 & 1,760 & 0.48 & 1.48 & 0.104 \\
\hline & 26 & \multirow{4}{*}{ Vertical } & 24 & 11.17 & 4,930 & & & \\
\hline & 27 & & 40 & 10.83 & 4,750 & & & \\
\hline & 29 & & 80 & 10.33 & 4,220 & & & \\
\hline & 30 & & 120 & 10.33 & 4,220 & & & \\
\hline
\end{tabular}


Table 3 Test Results of Dynamic Coefficient of Subgrade Reaction and Critical Damping Ratio. (After Preloading)

\begin{tabular}{|c|c|c|c|c|c|c|c|c|}
\hline \multirow{2}{*}{$\begin{array}{c}\text { Type of } \\
\text { Concrete } \\
\text { Block }\end{array}$} & \multirow{2}{*}{$\begin{array}{l}\text { Excited } \\
\text { Direction }\end{array}$} & \multirow{2}{*}{ Test No. } & \multirow{2}{*}{$\begin{array}{l}\text { Eccentric } \\
\text { Moment } \\
(\mathrm{kg} \cdot \mathrm{cm})\end{array}$} & \multicolumn{2}{|c|}{ Resonat Frequency } & \multicolumn{2}{|c|}{$\begin{array}{l}\text { Dynamic Coefficient of } \\
\text { Subgrade Reaction }\end{array}$} & \multirow{2}{*}{$\begin{array}{c}\text { Critical } \\
\text { Daping } \\
\text { Ratio } \\
h\end{array}$} \\
\hline & & & & $\underset{(\mathrm{cps})}{f}$ & $(\mathrm{rad} / \mathrm{sec})$ & $\underset{\left(\mathrm{kg} / \mathrm{cm}^{3}\right)}{k_{h}}$ & $\begin{array}{c}k_{v} \\
\left(\mathrm{~kg} / \mathrm{cm}^{3}\right)\end{array}$ & \\
\hline \multirow[t]{2}{*}{ L-Type } & Horizontal & $\begin{array}{l}1 \\
2 \\
3 \\
4 \\
5\end{array}$ & $\begin{array}{r}16 \\
43 \\
62 \\
103 \\
155\end{array}$ & $\begin{array}{l}9.6 \\
8.75 \\
8.0 \\
7.1 \\
6.3\end{array}$ & $\begin{array}{l}60.3 \\
55.0 \\
50.3 \\
44.6 \\
39.6\end{array}$ & $\begin{array}{l}2.34 \\
2.16 \\
1.50 \\
1.16 \\
0.795\end{array}$ & $\begin{array}{l}9.05 \\
6.93 \\
6.70 \\
5.36 \\
4.98\end{array}$ & $\begin{array}{l}0.091 \\
0.092 \\
0.103 \\
0.109 \\
0.127\end{array}$ \\
\hline & Vertical & $\begin{array}{l}6 \\
7\end{array}$ & $\begin{array}{r}90 \\
145\end{array}$ & $\begin{array}{l}14.4 \\
14.0\end{array}$ & $\begin{array}{l}90.5 \\
88.0\end{array}$ & & $\begin{array}{l}2.70 \\
2.55\end{array}$ & $\begin{array}{l}0.070 \\
0.070\end{array}$ \\
\hline \multirow[b]{2}{*}{ M-Type } & Vertical & $\begin{array}{r}8 \\
9 \\
10\end{array}$ & $\begin{array}{r}70 \\
114 \\
145\end{array}$ & $\begin{array}{l}14.3 \\
14.1 \\
14.1\end{array}$ & $\begin{array}{l}90.0 \\
88.5 \\
88.5\end{array}$ & & $\begin{array}{l}2.06 \\
2.00 \\
2.00\end{array}$ & $\begin{array}{l}0.097 \\
0.069 \\
0.060\end{array}$ \\
\hline & Horizontal & $\begin{array}{l}11 \\
12 \\
13 \\
14\end{array}$ & $\begin{array}{r}21 \\
44 \\
81 \\
118\end{array}$ & $\begin{array}{l}9.4 \\
8.7 \\
7.5 \\
6.6\end{array}$ & $\begin{array}{l}59.0 \\
54.6 \\
47.0 \\
41.4\end{array}$ & $\begin{array}{l}1.24 \\
1.15 \\
0.780 \\
0.55 \\
\end{array}$ & $\begin{array}{l}7.05 \\
5.15 \\
4.56 \\
4.50\end{array}$ & $\begin{array}{l}0.106 \\
0.081 \\
0.123 \\
0.151\end{array}$ \\
\hline \multirow{2}{*}{ S-Type } & Horizontal & $\begin{array}{l}16 \\
17 \\
18\end{array}$ & $\begin{array}{l}24 \\
40 \\
81\end{array}$ & $\begin{array}{r}12.2 \\
11.0 \\
9.2\end{array}$ & $\begin{array}{l}76.6 \\
69.0 \\
57.8\end{array}$ & $\begin{array}{l}1.47 \\
1.21 \\
0.826\end{array}$ & $\begin{array}{l}5.50 \\
4.44 \\
3.32\end{array}$ & $\begin{array}{l}0.127 \\
0.116 \\
0.133\end{array}$ \\
\hline & Vertical & $\begin{array}{l}20 \\
21 \\
22\end{array}$ & $\begin{array}{r}63 \\
92 \\
120\end{array}$ & $\begin{array}{l}14.9 \\
14.6 \\
14.15\end{array}$ & $\begin{array}{l}93.5 \\
91.6 \\
89.0\end{array}$ & & $\begin{array}{l}1.60 \\
1.54 \\
1.45\end{array}$ & $\begin{array}{l}0.064 \\
0.067 \\
0.062\end{array}$ \\
\hline
\end{tabular}

value increase considerably due to the effect of soil stabilization method.

\section{3-2 Critical Damping Ratio}

Fig. 13-(a) and (b) show the relationship between the critical damping ratio obtained from the
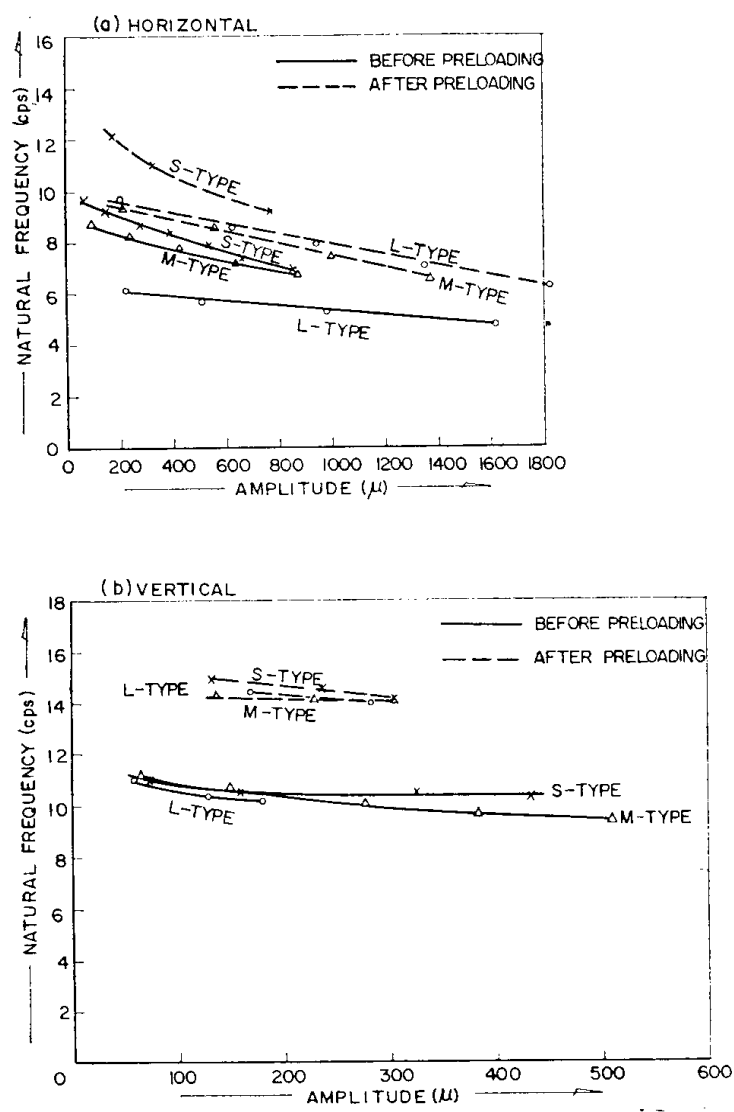

Fig. 11 Relationship between Natural Frequency and Resonant Amplitude resonance curves and the resonant amplitude. It is observed from Fig. 13-(a) that the critical damping ratio $h$ is function of the dimension of foundation, i.e., $h$ is larger for thin foundation than for thick foundation while the base area is constant. Also, it is observed that according to increasing amplitude the critical damping ratio $h$ increase.

There are two kinds of damping, the loss of energy through propagation of waves away from the immediate vicinity of the footing, and the internal energy loss within the soil due to hysteretic and viscous effect. The radiational damping seems to be superior to the internal damping, then the test results are plotted in theoretical curves ${ }^{1)}$ for radiation damping as shown in Fig. 14. The experimental values are located at the middle of two theoretical curves, because these values are the data for the coupled vibration of horizontal and rotational vibration.

The critical damping ratio $h$ increases when the amplitude increases.

The reason for this seems to be due to the hysteretic damping. In horizontal excitation, the critical damping ratio $h$ increase clearly after preloading. However, in vertical excitation the opposite tendency is 

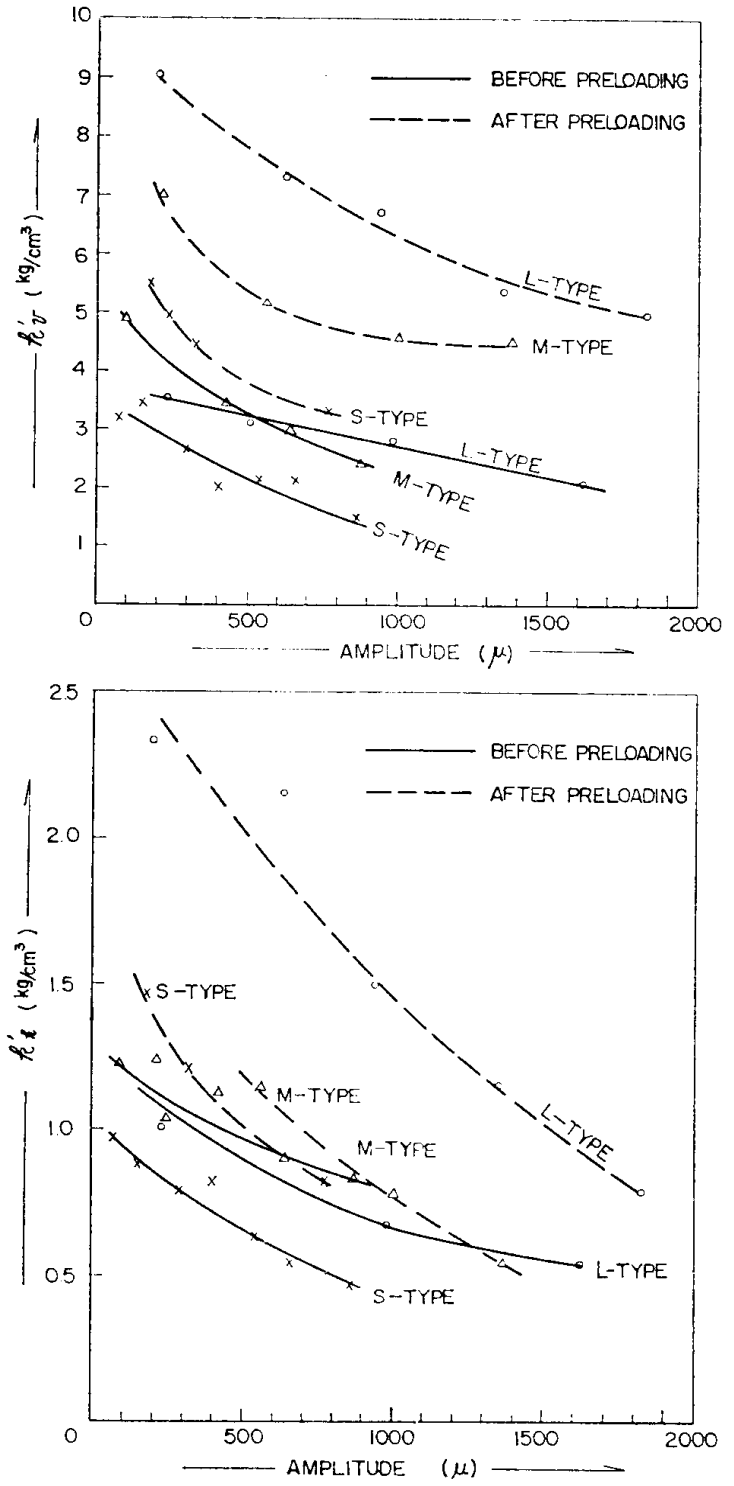

Fig. 12 Relationship between $k_{v}{ }^{\prime}, k_{h^{\prime}}$ and Resonant Amplitude
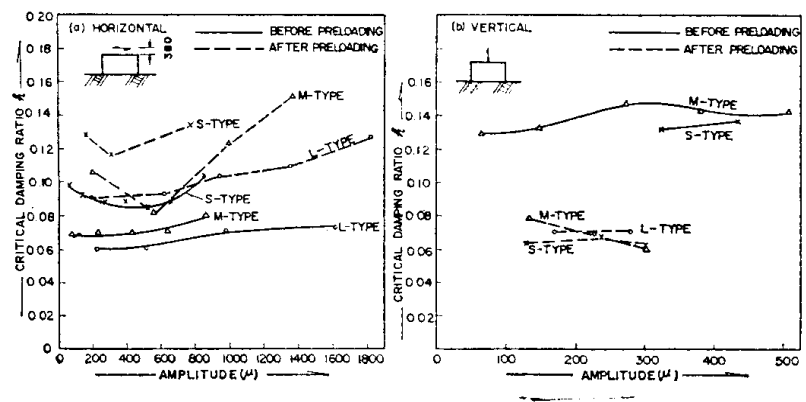

Fig. 13 Relationship between Critical Damping Ratio and Resonant Amplitude

observed (see Fig. 13-(b)). The reason for this phenomenon is not clear.

3-3 Relationship Between Shear Wave Velocity and $N$-Value

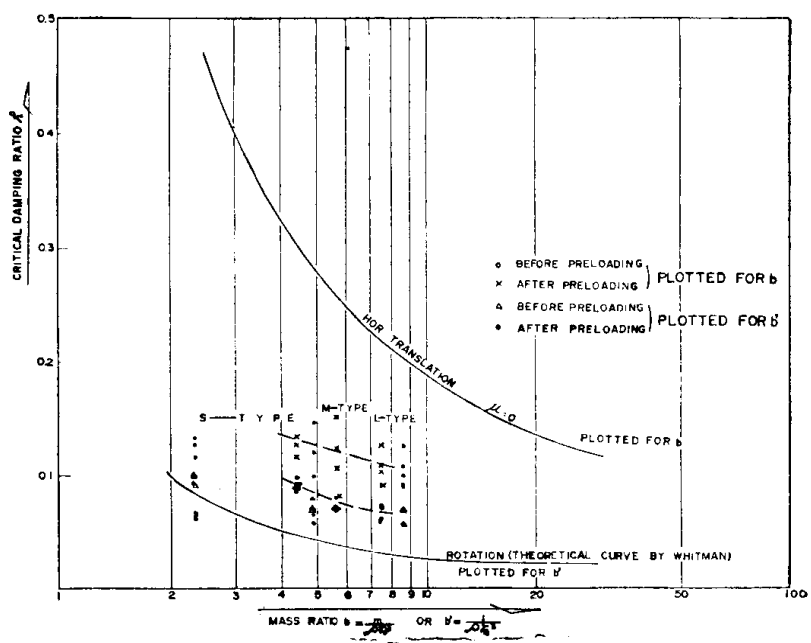

Fig. 14 Relationship between Critical Damping Ratio $h$ and Mass Ratio $b$

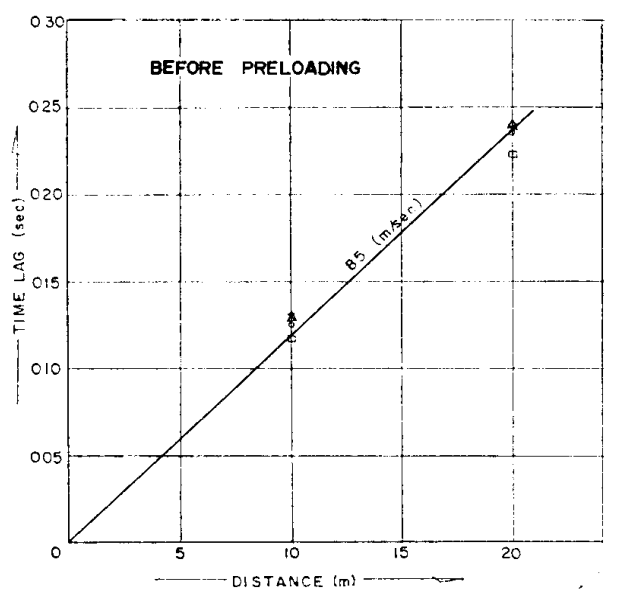

Fig. 15-(a) Time Lag-Distance Curves for Evaluating Shear Wave Velocity by Method of Hitting a Wooden Plate Horizontally

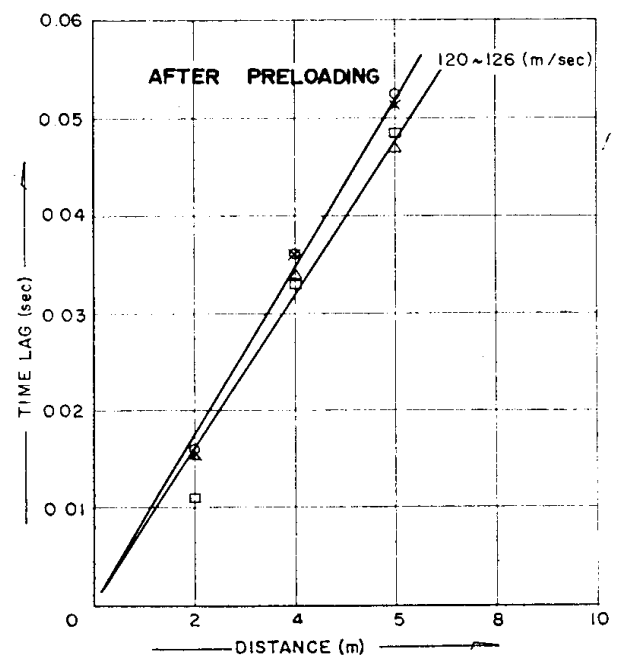

Fig. 15-(b) Time Lag-Distance Curve for Evaluating Shear wave velocity by method of hitting a Wooden Plate Horizontally

The time-lag-distance curves getting from the hitting the wooden plate method are shown in Fig. 15 -(a) and (b). The phase velocity increase to $120 \mathrm{~m} / \mathrm{sec}$ from $85 \mathrm{~m} / \mathrm{sec}$ due to the effect of preloading. Fig. 16 shows a relationship between shear wave velocity $V_{S}$ and $N$-value proposed by Imai et al ${ }^{2}$. The experimental data are plotted in the figure and show a good coincident with proposed relations- 
hip. Fig. 17 show the relationship between $V_{S}$ and $N-$ value proposed by $\mathrm{Kanai}^{3}$ and our test results are plotted in it. It is observed from this figure that the tendency coincident appropriately, but our test values of $V_{S}$ are a little larger than proposed values.

3-4 Relationship between Shear Wave Velocity and Void Ratio

Hardin and Richart ${ }^{1}$ presented the relationship between shear wave velocity $V_{S}$ and void ratio $e$, for varying values of the confining pressure as shown in Fig. 18 by laboratory test. Our field test results are plotted in this figure too. From this result, the confining pressure is observed about $0.08 \sim 0.15 \mathrm{~kg} / \mathrm{cm}^{2}$, which is equivalent confining pressure at $1 \mathrm{~m}$ depth under the surface of ground, for the measured velocity on the surface of ground.

3-5 Evaluation of Elastic Modulus by Shear Wave Velocity $V_{S}$ and Dynamical $k$-Value

The elastic modulus of the test ground shall be evaluated from test results for dynamical $k$-value and shear wave velocity $V_{S}$. The shear modulus $G$ is evaluated from the test results of the dynamical $k$-value using the several formulae, which are the static $k$-value on elastic half media, shown in Table 4 and from the shear wave velocity using the following formula :

$$
V_{S}=\sqrt{G / \rho}
$$

where $\rho$ is density of soil.

Fig. 19-(a) shows the theoretical relationship between the dynamical $k_{v}{ }^{\prime}$-value $\left(K_{\theta} / I a\right)$ for coupled vibration of sliding and rocking vibration and the shear modulus $G$ caluculated from the formulae shown in Table 4. Similarly the same relationship for vertical vibration $\left(k_{v}\right)$ are shown in Fig. 19-(b). Substituting the test results for $k_{v}{ }^{\prime}$ and $k_{v}$ into these figure, the shear modulus $G$ can be assumed. The dynamical $k$-value is approximately in inverse proportion to the accelelation of center of gravity of the foundation as shown in Fig. 20-(a) and (b). Then, the values at which the accelelation of center of gravity is equal to zero in Fig. 20 are used to evaluate the shear modulus from Fig. 19-(a) and (b).

The shear modulus $G$ evaluated from the test results of the dynamical $k$-value and the shear wave velocity $V_{S}$ are shown in Table 5. It is observed from Table 5 that are shown in Table 5. It is observed from Table 5 that the maximum values of shear modulus $G$ evaluated from dynamical $k$-value in the case of assuming triangular pressure distribution in rotational mode coincide prety well with the values evaluated from the shear wave velocity $V_{S}$. It is confirmed that after preloading the shear modulus of the ground increase to be twice larger than it at proto ground.

3-6 Study on Applicability of Elastic Theory

The simulation of experimental values by means of elastic theory is made to study on the applica-

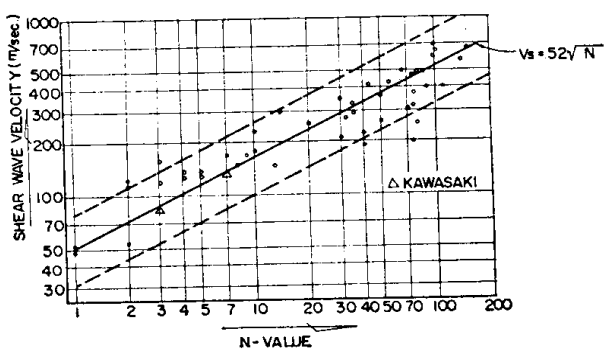

Fig. 16 Relationship between Shear Wave Velocity and $N$-Value

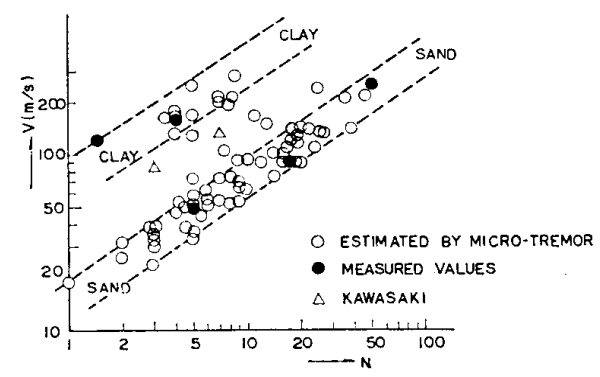

Fig. 17 Relationship between Shear Wave Velocity and $N$-Value

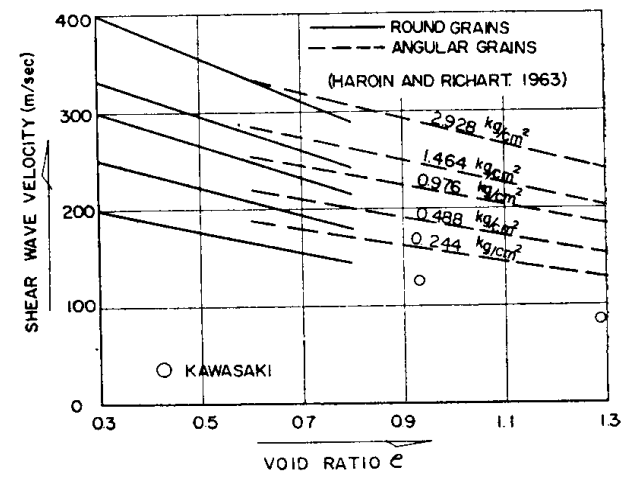

Fig. 18 Shear Wave Velocity Versus Void Ratio and Confining Pressure, for Quartz Sand

\begin{tabular}{|c|c|c|}
\hline MOTION & PRESSURE DIST. & SPRING CONSTNT \\
\hline & CIRCULAR $B$ & BASE \\
\hline \multirow{2}{*}{ VERTICAL } & UNIFORM & $K_{r}=\frac{\pi a \mu}{1-\nu} \quad\left(K_{9} / \mathrm{mm}\right)$ \\
\hline & RIGID BASE & $K_{\nu}=\frac{4 a \mu}{1-\nu} \quad(\mathrm{Ka} / \mathrm{m})$ \\
\hline \multirow[b]{2}{*}{ HORIZONTL } & UNIFORM & $K_{k}=\frac{2 \pi a \mu}{2-\nu} \quad\left(K_{0} / \mathrm{km}\right)$ \\
\hline & RIGID BASE & $K_{k}=\frac{8 a \mu k}{2-\nu} \quad\left(\mathrm{K}_{\mathrm{g}} / \mathrm{cm}\right)$ \\
\hline \multirow[b]{2}{*}{ ROCKING } & TRIANGULAR & $K_{*}=\frac{\pi \mu a^{3}}{2(1-\nu)}\left(k_{0} \cdot c \eta_{0}\right)$ \\
\hline & RIGID BASE & $K_{0}=\frac{8 \mu a^{3}}{3(1-D)}\left(k_{a} \cdot \mathrm{cm} / \mathrm{f}_{0}\right)$ \\
\hline
\end{tabular}

Table 4 Spring Constants for Circular Base Resting on Elastic HalfSpace 


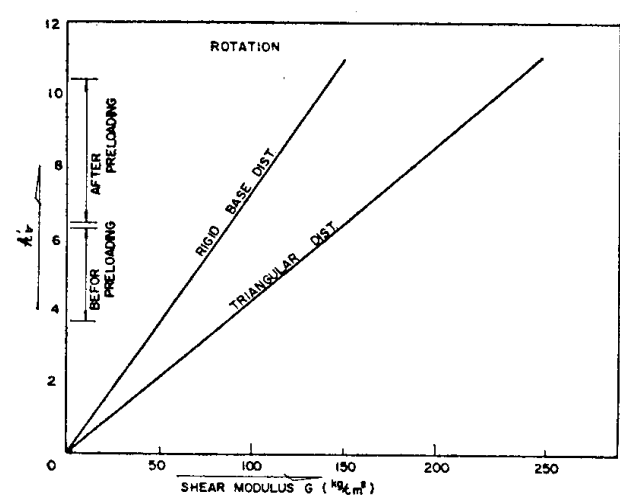

Fig. 19-(a) Relationship between $k_{v}{ }^{\prime}$ and Shear Modulus $G$

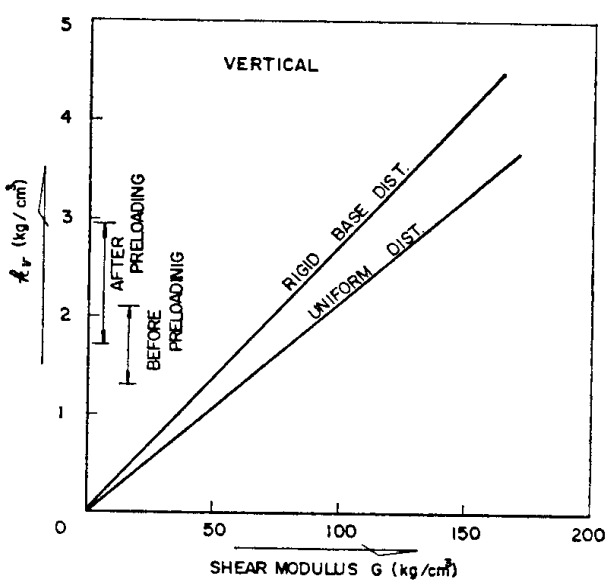

Fig. 19-(b) Relationship between $k_{v}$ and Shear Modulus $G$

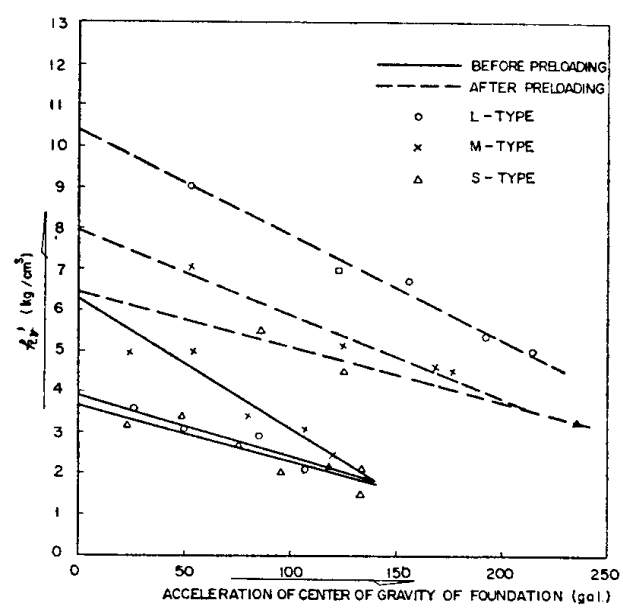

Fig. 20-(a) Relationship between $h_{v}{ }^{\prime}$ and Acceleration of Center of $\mathrm{Gr}$. avity of Foundation

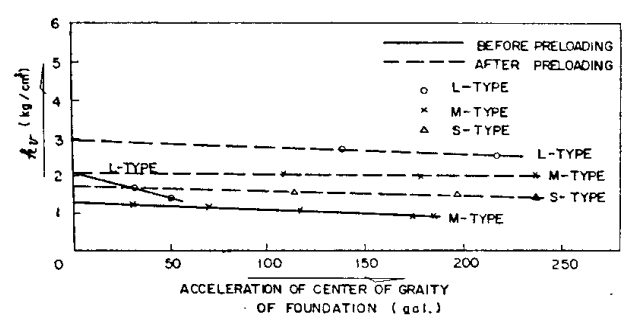

Fig. 20-(b) Relationship between $k_{v}$ and Acceleration of Center of $\mathrm{Gr}$ avity of Foundation

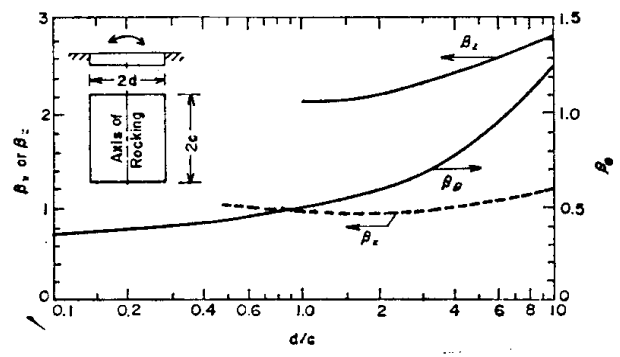

Fig. 21 Coefficients $\beta_{x}, \beta_{x}$ and $\beta_{x}$ for rectangular footings (after Whitman and Richart, 1967)

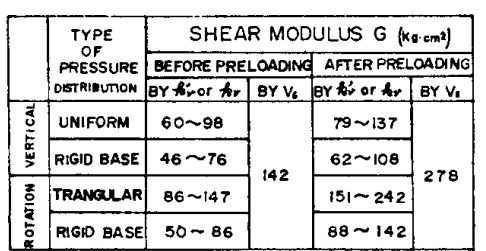

Table 5 Comparison of Shear Modulus $G$

\begin{tabular}{|c|c|c|c|}
\hline Motion & Mass Ratio & Spring constont & $\begin{array}{l}\text { Critical Damping } \\
\text { Aotio }\end{array}$ \\
\hline Verrical & $B_{2}=\frac{1-\nu}{4} \cdot \frac{m}{\rho r_{1}^{3}}$ & $K_{z}=\frac{G}{1-D} \cdot \beta_{2} \sqrt{4 c d}$ & $h_{z}=\frac{0.425}{\sqrt{\theta_{z}}}$ \\
\hline Horizontal & $B_{x}=\frac{7-8 \nu}{32(1-\nu)} \cdot \frac{m}{\rho 0_{0}^{2}}$ & $K_{x}=4(1+2) G \beta_{x} \sqrt{c 0}$ & $h_{x}=\frac{0.28 B}{\sqrt{B_{x}}}$ \\
\hline Rocking & $a_{0}=\frac{3(1-\lambda)}{8} \cdot \frac{L}{a_{0}^{3}}$ & $K_{\theta}=\frac{\sigma}{1->} \cdot \dot{\theta}_{\theta} \theta \overrightarrow{\theta c \alpha^{2}}$ & $n_{0}=\frac{0.15}{\left(1+B_{2}\right) \sqrt{B_{0}}}$ \\
\hline
\end{tabular}

Note : volues : or $\beta_{2}, \beta_{x}$, and $\beta_{8}$ ore given in Fig. 21 for varicus walues of ate

Table 6 Mass Ratio, Spring Constant and Critical Damping Ratio for Rigid Rectangular Footing Resting on Elastic Half Space.

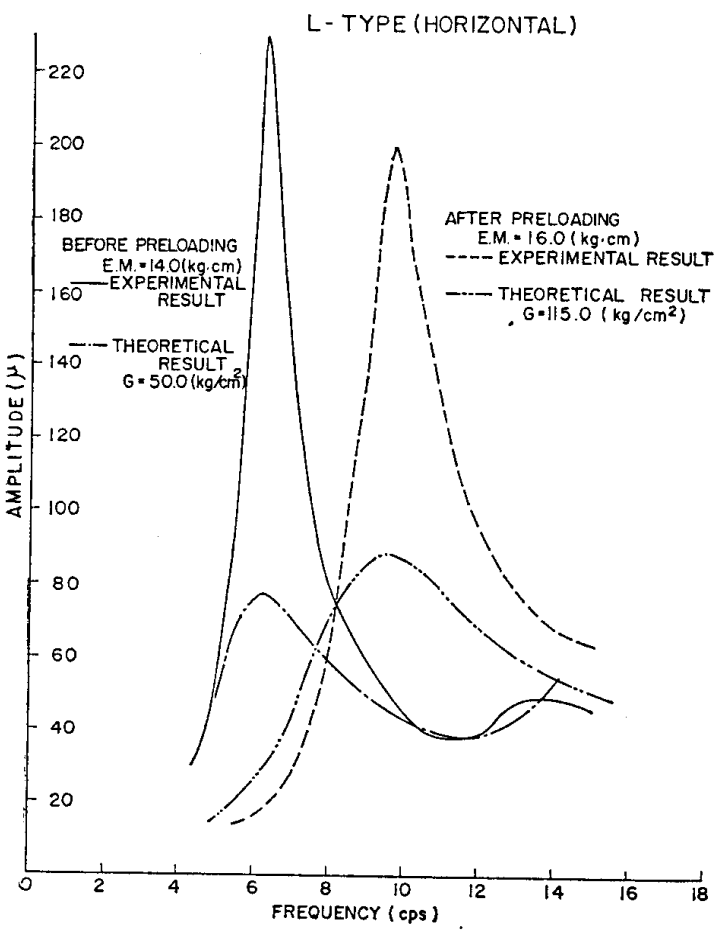

Fig. 22 Comarison of Experimental and Theoretical (Elastic) ${ }^{4) 5}$ Results 


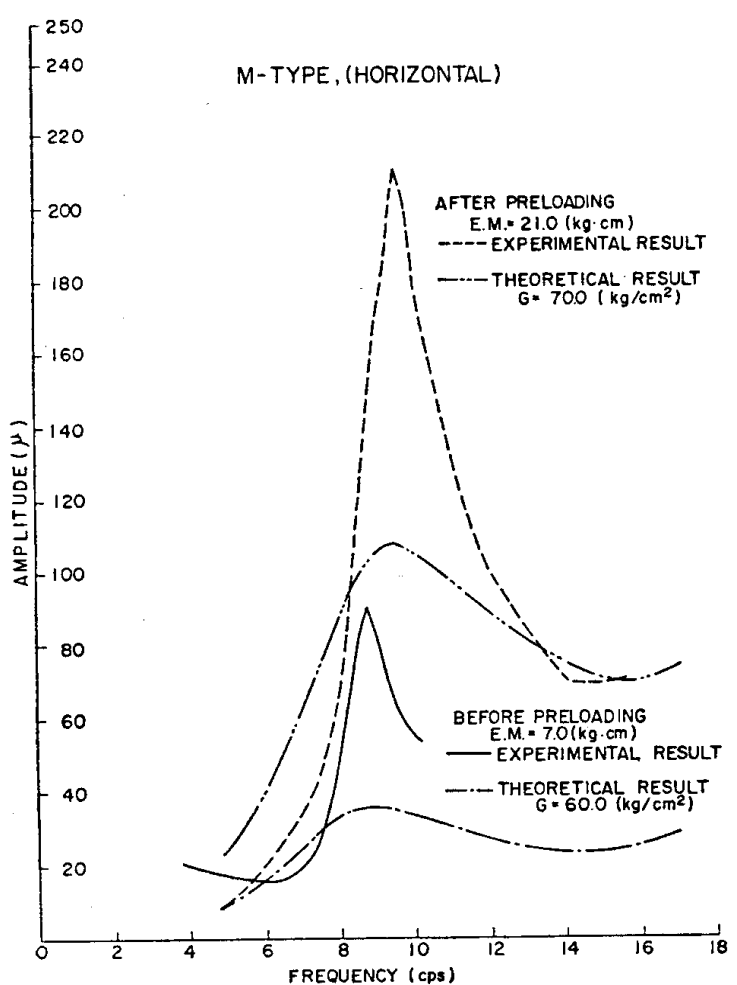

Fig. 23 Comarison of Experimental and theoretical (Elastic) ${ }^{45)}$ Results

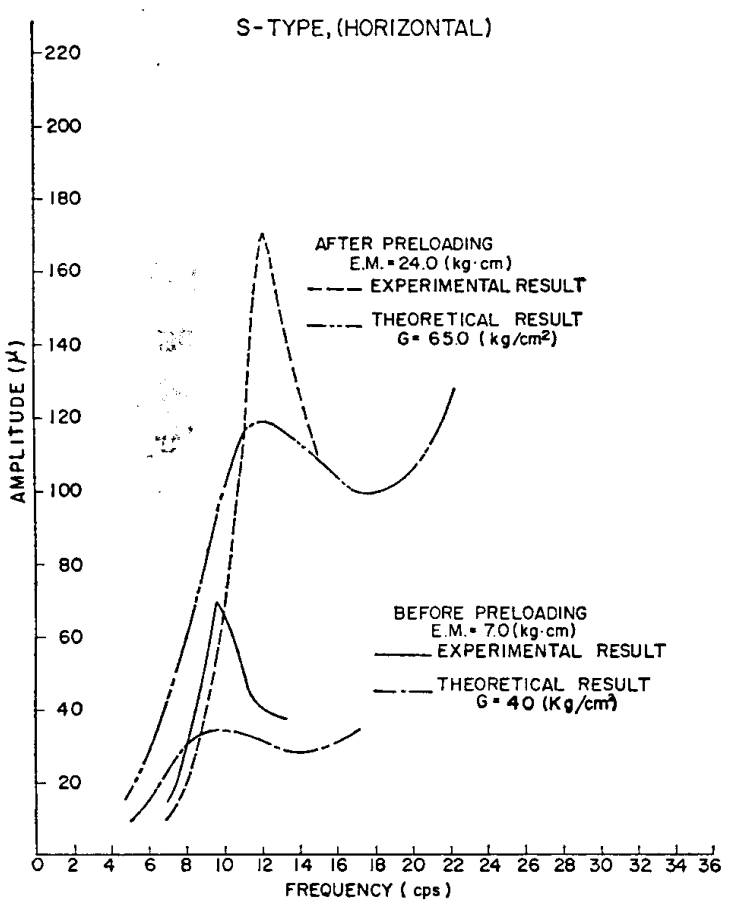

Fig. 24 Comarison of Experimental and theoretical (Elastic) ${ }^{455}$ Results
L-TYPE, (VERTICAL)

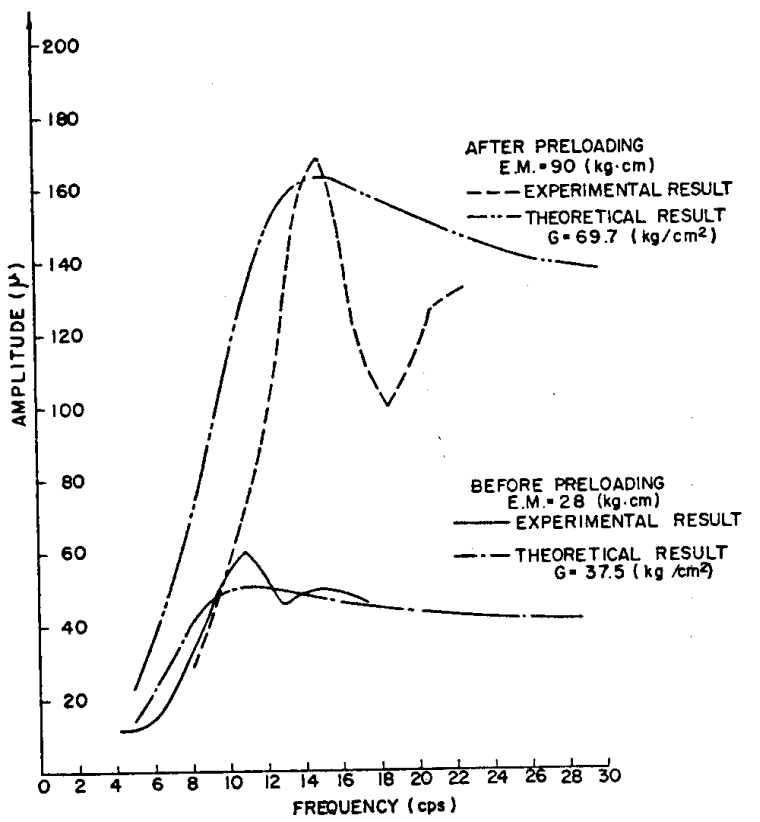

Fig. 25 Comarison of Experimental and Theoretical (Elastic) ${ }^{4) 5}$ Results

M-TYPE, (VERTICAL)

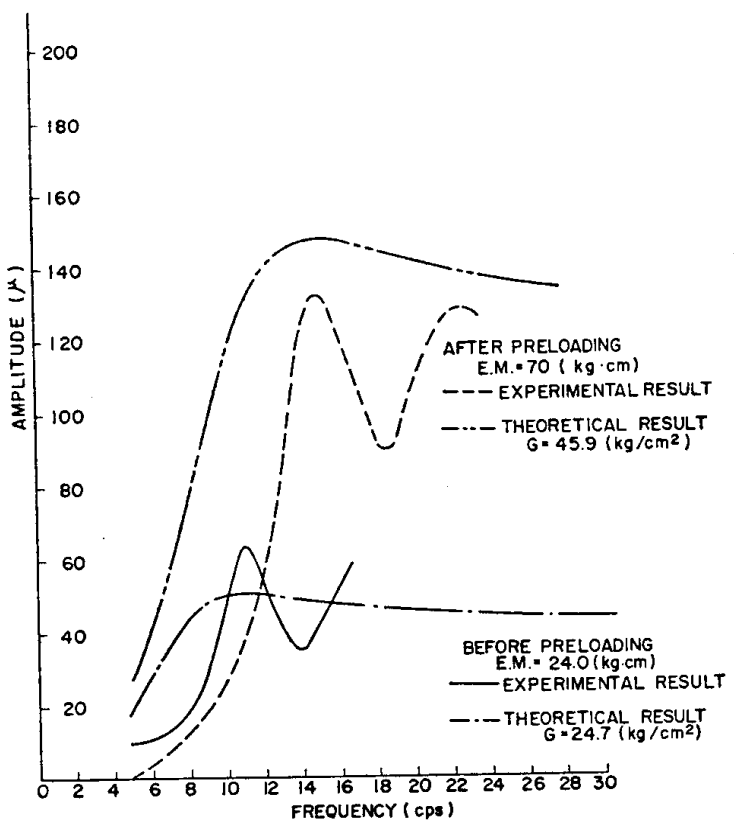

Fig. 26 Comarison of Experimental and Theoretical (Elastic) ${ }^{4) 5}$ Results

bility of elastic theory assuming the ground as the homogeneous, isotropic, elastic semi infinite body and calculating the response of a footing resting on it. The convenient method by Lysmer $^{4,5)}$ et al. is used, and which outline is as follows. The equivalent radius of a rectangular footing is determined by the following:

For translation $: r_{0}=\sqrt{\frac{4 c d}{\pi}}$

For rocking $\quad: r_{0}=\sqrt[4]{\frac{16 c d^{3}}{3 \pi}}$

Fot torsion $\quad: r_{0}=\sqrt[4]{\frac{16 c d\left(c^{2}+d^{2}\right)}{6 \pi}}$ 


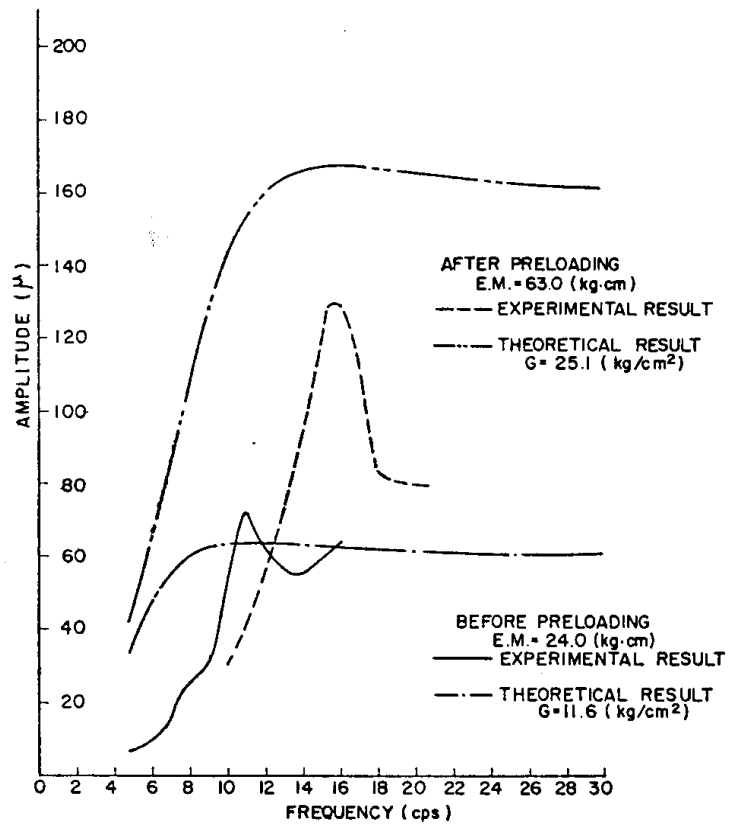

Fig. 27 Comarison of Experimental and Theoretical (Elastic) ${ }^{4) 5}$ Results

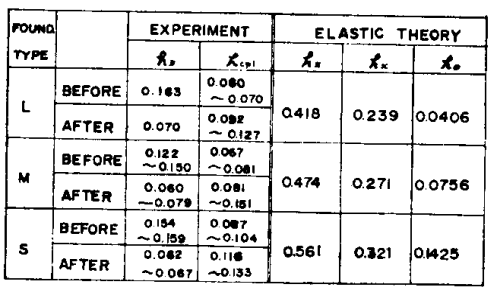

Table 7 Comparison of Critical Damping Ratio

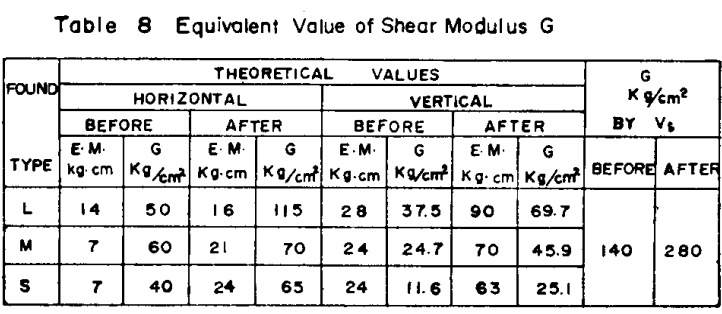

Table 8 Equivalent Value of Shear Modulus $G$

inwhich

$2 c=$ width of the footing (along axis of rotation for the case of rocking),

$2 d=$ length of the footing (in the plane of rotation for rocking).

The spring constants and the critical damping ratio of ground are calculated from the formulae listed in Table 6.

The experimental values for minimum eccentric moment of two kinds of test, i.e., horizontal and vertical excitations, for each footing are compared with the theoretical values in Fig. 22 thru Fig. 27, where the shear moduli used in the calculation of elastic theory are selected as coinciding the theoretical resonant frequencies with the corresponding measured resonant frequencies.

It is observed clearly from these figures that the results of elastic theory give too large damping in comparison with experimental values. This reason may be due to the fact that the ground is considered to be elastic half-space in elastic theory, while the real ground is composed of layered medium.

Then, the damping may be decreased by the effects of reflected wave from the under solid stratum. Consequently, in the case of using elastic theory, it is important to examine the layered condition of ground carefully and determine the reasonable value of damping coefficient. Authors experiences show that it is unreasonable to take the value over 0.2 as the critical damping ratio. The experimental and corresponding theoretical values for the critical damping ratio are shown in Table 7 for reference. Then, the equivalent values of shear modulus $G$ from shear wave velocity are shown in Table 8 . It is observed that the theoretical values are smaller than the values derived from the shear wave velocity considerably. It may be the reason that the strain of the soil in the forced vibration test is larger than it in the hitting the plate method.

Also, it is observed that the larger values of shear modulus were obtained in the case of thick foundation than thin foundation. This reason may be explained by the difference of confining pressure, i.e. the confining pressure of thick foundation is larger than thin foundation.

\section{Conclusion}

It is desirable that the elastic modulus of soil shall be assumed from a laboratory test results in a future. For this purpose, further investigation based on the many laboratory and field test results should be necessary.

\section{References}


1) R.V. Whitman and F.E. Richart, Jr. (1967)

"Design Procedures for Dynamically Loaded Foundations", Journal of the Soil Mechanics and Foundations Division, ASCE, Vol. 93, No. SM 6, Proc. Paper 5569, Nov., pp. 169-191.

2) T. Imai, M. Yoshimura (1969)

"Meaning of Measurement of Elastic Wave Velocity on Soft Soil", Proceedings, 4 th Conference on Soil Mechanics, Soil Mechanics Institute of Japan, pp. 101-106.

3) T. Kanai (1968)

"Earthquake Engineering”, Structural Mechanics for Architecture, Series No. 1, Shokokusha Book Co., Ltd., pp. 39.

4) Lysmer, J. (1965)

"Vertical Motion of Rigid Footings", Dept. of Civil Eng., Univ. of Michigan Report to WES Contract Report No. 3-115 Under Contract No. DA-22-079-eng-340; also a ph.D. dissertation, Univ. of Michigan, Aug.

5) F.E. Richart, Jr., J.R. Hall, Jr., R.D. Woods (1970)

"Vibration of Soils and Foundations", Prentice-Hall Ins. (Englewood Cliffs, New Jersey). 


\title{
地盤安定工法 (Vibro Composer および Preloading) が地盤の弾性定数に与える影響
}

\author{
正会員山本 鎮 男* 正会員 関 \\ 正会員鈴 木 延 明**
}

\section{まえがき}

地盤の影響を考慮した構造物の動的設計を行なうため には，地盤の弾性定数を知る必要がある。もし地盤の弹 性定数と，士の物理定数あるいは $N$ 值，間偿比，圧縮 強度のような地盤条件をあらわすある指数との関係が， 明らかにすることができるならば，地盤を考虑した構造 物の動的設計はより簡単になる。この論文では, 地盤の 弹性定数を基礎の強制振動実験と地盤のせん断波速度の 測定結果から推定し，地盤条件を示寸諸定数と関連づけ て検討した。また，バイブロコンポーザーとプレローデ イングが地盤の弾性定数におよぼす影響について検討し た。

\section{1. 地盤条件}

実験場所と試験地盤の土質条件を Fig. 1, 2 に示し た。表層 ( $F$ 層) とそれにつづく砂層 ( $\mathrm{S}$ 層) を強化 し，不等沈下を防ぐために，プレローディングとサンド ドレインによる土質安定工法が施工された。Fig. 3 に 時間-載荷曲線と時閒-沈下曲線を示した。プレローディ ング前後の土質柱状図は Fig. 2 に示すとおりである。

土質安定工法の結果 $N$ 值は $\mathrm{F}$ 層で 3 から 7 に, $\mathrm{S}$ 層で 7 から 20 に増加した。

土の室内試験結果を Table. 1 に示した。

\section{2. 実験方法}

サンドドレインとプレローディングが地盤の弾性定数 に与える影響を知るために, プレローディング前と後に それぞれ模型基礎の強制振動実験と $S$ 波速度の測定を 行なった。強制振動実験用の模型基整は Fig. 4-(a),(b) に，各実験の地盤レベルは Fig. 2 に示すとお りであ る。模型基礎の強制振動実験では，基礎上に据付けられ た起振機によって，振動数を段階的に変化させながら加 振し, 基礎の各点の振幅を振動計で測定し共振曲線と共 振時の振動モードを得た。なお，加振位置は，基整上面 から $38 \mathrm{~cm}$ の高さであり, 共振曲線を得るための観測 点は Fig. 4-(a), (b) 中に・印で示した。加振は, 上下, 水平の二方向について行なった。

\footnotetext{
*千代田化工建設株式会社 技術総合研究所スタッフ研究員 工博, ** 同研究員

(昭和 46 年 4 月 16 日稿本受理，討諭期限昭和 47 年 1 月末日)
}

水平加振は，加振位置が基礎の重心と一致していない ため, 水平動と回転動の連成した振動となっている。以 下の図掞よび表中の VERTICAL, HORIZONTAL の 表示はそれぞれ加振方向を示している。この実験は，起 振機の偏心モーメントを変え，数回くり返した。これら の data から, 地盤の動的 $k$ 值と減衰常数を求めた。 地盤のせん断波速度は次のよ5にして求められた。長さ $1 \mathrm{~m}$, 幅 $40 \mathrm{~cm}$, 厚さ $3 \mathrm{~cm}$ の木製の板を, 平坦になら し，接触をよくするためにセメント粉をまいた地表面に 挔き，その上に摩擦力を増すための重しとして数人がの った。この板の端部を木製のかけやで水平にたたくこと によってせん断波を発生させた。

こうした発生したせん断波を Fig. 4-(a),(b) に示し たように地表面に配置された地震計により，同時記録を とり, 走時曲線から位相速度を求めた。

\section{3. 実験結果および考察}

\section{3-1 共振曲線および地盤の復元力}

基礎上で測定した強制 振動実験による共振曲線を Fig. 5 10 に示した。実験から求めた動的 $k$ 值と減衰 常数の一覧を Table 2 と 3 に示した。共振曲線からは 振幅が増大寸るにつれて，共振振動数が低下するのが観 察される。Fig. 11 に共振振動数と共振振幅の関 倸を Fig. 12 に水平ロッキング 振動から求めた動的 $k$ 值と 共振振幅の関係を示した。これらの図から，地盤の復元 カのアンダーリニヤー 特性が明瞭にみられる。Fig. 11 と 12 にはプレローディング前後の結果が同一図上にプ ロットしてあるが，この図からプレローディング後にお いては, 土質安定工法の効果によって，共振振動数と動 的 $k$ 值が增大しているのが観察される。

\section{3 -2 減衰常数}

Fig. 13-(a),(b) 亿共振曲線から求めた減衰常数と共 振振幅の関倸を示した。

Fig. 13-（a）によれば，減衰常数 $k$ は基䃈形状の関 数となっている。すなわち， $k$ は基礎底面積が一定の場 合，厚い基礎より，薄い基礎の方が大きい，また，この 図から， $k$ は振幅の増大につれて増加しているのが観察 される。一般に，減衰には二つの種類がある。基礎底面 から地盤への波動伝播によるエネルギー損失としての地 
下逸散滅衰と, 土の履歴特性と, 粘性による内部減衰で ある。

地下逸散減衰の方が優勢であると考えられるので，実 験結果を, 地下逸散減衰の理論曲線 ${ }^{11}$ に対しプロットし てみた (Fig. 14)。

実験值が horizontal と rotation の二つの理論曲線 の中間にあるのは，これらの data が水平 rocking 振 動から求めたものだからである。減衰常数 $k$ が振幅の 増加につれて, 増大しているのは, 履歷減衰によるもの であろう。

水平加振においては， $k$ はプレローディング後明らか に増加しているが，上下加振においては逆の傾向になっ ている。この理由は明らかではない。

3 -3 せん断波速度と $N$ 值の関係

板たたき法から求めた走時曲線を Fig. 15-(a),(b) に 示す。プレローディングの効果により，位相速度は 85 $\mathrm{m} / \mathrm{sec}$ から $120 \mathrm{~m} / \mathrm{sec}$ に増加している。

Fig. 16 は今井 ${ }^{2)}$ が提案したせん断波速度 $V_{S}$ と $N$ 值の関係であり，これに実験值をプロットしてみたが， よく一致している。

Fig. 17 は金井が提案したせん断波速度と $N$ 值の関 係に，実験值をプロットしたものである。傾向的にはほ ぼ一致しているが，今回の実験值の方が提案值よりも若 干，高めにでているようである。

3-4 せん断波速度と間幥比の関倸

Hardin と Richart ${ }^{1}$ は は室内実験 の結果から, 種々の confining pressure に対してせん断波速度 $V_{S}$ と閒偿 比 $e$ の関係を Fig. 18 のように示した。

実験值をこれにプロットしたが，これによれば confining pressure は約 $0.08 \sim 0.15 \mathrm{~kg} / \mathrm{cm}^{2}$ に相当し, こ れは地表面から，約 $1 \mathrm{~m}$ の媣さに打ける confining pressure に相当する。

3-5 動的 $k$ 值とせん断波速度による地盤の弾性定 数の推定

実験地盤におけるせん断弾性係数 $G$ は, Table 4 に 示した半無限弾性体上にお沙る静的 $k$ 值の理論式を用 いることによって，動的 $k$ 値の実験值加ら推定するこ とにした。また，次式を用いることによって，せん断波 速度の実験值から推定することができる。

$$
V_{S}=\sqrt{G / \rho} \rho: \text { 土の密度 }
$$

Fig. 19-(a) は, Table 4 の各式から求めた, 水平と 回転の連成振動の場合の垂直方向動的 $k$ 值 $k_{v}{ }^{\prime}\left(K_{\theta} / I a\right)$ とせん断弾性係数 $G$ の関係を示したものである。上下 振動に対する同様の関係を Fig. 19-(b) に示した。こ れらの図に $k_{v}{ }^{\prime}$ と $k_{v}$ の実験值を代入すれば, せん断弾 性係数 $G$ が推定できる。動的 $k$ 值は Fig. 20-(a),(b) に示したように，ほぼ基礎の重心加速度に反比例する。 したがって, Fig. 19-(a),(b) からせん断弾性係数 $G$
を推定するにあたっては，便宜上 Fig. 20 において基 礎の重心加速度が 0 の場合の值を用いることとする。

動的 $k$ 值とせん断波速度の実験值加求めた, せん 断弾性係数 $G$ を Table 5 に示した。

Table 5 によれば，回転モードと，応力分布を三角形 と仮定して, 動的 $k$ 值から求めたせん断弾性係数 $G$ の 最大值とせん断波速度から求めた $G$ の值が非常によく 一致していることがわかる。また，プレローディング後 は, 地盤のせん断弹性係数が 2 倍に増加したことが確認 される。

3-6 弾性理論の適用性の検討

地盤を均質な等方性の半無限弹性体と仮定し, その地 盤上の基礎の応答を解析する弾性理論によって, 実験值 のシミュレィションを行ない，弾性理論の適用性につい て検討した。弾性理論としては，Lysmer らによる簡便 法を用いた。すなわち，

矩形基礎の等価半径は

上下動, 水平動 $r_{0}=\sqrt{\frac{4 c d}{\pi}}$

$$
\text { ロッキング } \quad r_{0}=\sqrt[4]{\frac{16 c d^{3}}{3 \pi}}
$$

ねじり

$$
r_{0}=\sqrt[4]{\frac{16 c d\left(c^{2}+d^{2}\right)}{6 \pi}}
$$

ここで

$2 c$ =基礎幅（ロッキングの場合は，回転軸に平 行)

$2 d=$ 基礎長（ロッキングの場合は，回転軸记直角 方向）

バネ常数と減衰常数は Table 6 を用いる。

各試験基礎について，水平ロッキング振動，上下振動 の実験からそれぞれ，偏心モーメント最小のものをえら び, 弹性理論による共振振動数を実験値に等置して解い た共振曲線を実験值と対比して, Fig. 22〜27 に示す。 一見して明らかなように, 弾性理論による解は, 過大な 減衰を与えていることがわかる。これは，弾性理論にお いては，地盤を半無限弾性体としているが，実際の地盤 は成層をなしているため，下層の固い層からの反射波の 影響により，理論值よりも低い值となるものと思われ る。したがって, 設計において, 弾性理論を用いる際に は, 地盤の成層状態を考慮に入れて, 適切な減衰常数を 仮定することが重要である。筆者らの経験によれば，減 衰常数としては 0.2 以上の值をとることは適切ではな いと思われる。Table 7 亿参考のために, 減衰常数の実 験値と理論值を対比して示した。

次に, この計算値から求めたせん断弾性係数の值を Table 8 に示した。この計算值は, 板たたき実験による せん断波速度から求めた值に比べてかなり小さい值とな っている。これは，板たたきにくらべて，歪が大きいた 
めと思われる。，また，基礎高が大きいものほど $G$ が大 きな值をとっているのは, confining pressure の増加 による影響であろう。

むすび
今後, 地盤の弾性定数が, 土の室内試験結果から推定 できるようになることが望まれる。このためには，室内 試験と野外実験の結果を種々の角度から比較, 検討する ことが必要であろう。 


\title{
THEORETICAL STUDY ON OSCILLATORY 'TENDENCIES OF' CYLINDRICAL STRUCTURES IN NATURAL WINDS (3)
}

\author{
Analysis of Some Practical Phenomena-- \\ by Dr. MORIHISA FUJIMOTO, Prof., Tokyo Inst. of Tech., TAkESHI \\ OHKIMA, Graduate Student, Tokyo Inst. of Tech., Members of A.I.J.
}

This paper checks the validity of the theory shown in the former paper.

Two examples are calculated. One is the aerodynamic behavior of the model of 1-mass 2 freedom system stood vertically in the open*. The other is the case of the steel stack of alaout $90 \mathrm{~m}$ high. The former provides effective data on the beat phenomeon and the latter is an example of aeroelastic: behaviors which have never yet sufficiently evaluated by analytical approaches.

The calculated results agree with the measured. This showes the validity of the approach.

* The cylinder is $0.37 \mathrm{~m}$ in diameter and $1.88 \mathrm{~m}$ in length.

\section{EXPERIMENTAL STUDY OF BRACING BEAM-COLUMNS}

by Dr. TOSHIRO SUZUKI. Assistant Prof, of Tokyo Institute of Tech.. Anut TETSURO ONO. Assistant of Tokyn Instifute of Tech.. Members of A.I.J.

The purpose of this paper is to investigat problems of the buckling strength and bracing spaces for heam-columm by experimental analysis. This experiments include two experimental series $A$ and $B$.

The object of A-series is to investigate the lateral buckling strength of beam-column. In this experiment, new spherical block is used. Experimental values of buckling strength are fairly good approximation to theoretical values and the behavior of deformation is good.

From experimental results, we find that the increase of post buckling strength is a little. Then, if we take notice of the strength of the members, we may take the post buckling strength into considerate at design the members. However, we can not expect the deformation capacity of the nonbrced beam-column.

B-series is made experiment to explain the bracing space of beam-column from point of view of the plastic steel design. The theoretical ground of bracing space is the theory of M.G.Lay. In generally, there are two foundamental optimum condition to consider the bracing space of beam-column.

1) The attainment of the maximum in-plane moment capacity.

2) The attainment of arotation at which local buckling occurs in member.

From these experimental results, we can not expect the rotation capacity after maximum in-plane moment capacity. In particular, this tendancy is remarkable in the beam-column subjected two end moments. Therefor, deciding the bracing space of beam-column, is is apropriate to adopt the first optimum condition.

U.D.C. $624.131 .5: 624.138 .4$

\section{EFFECTS OF VIBRO-COMPOSER AND PRELOADING ON THE ELASTIC MODULUS OF SOIL}

\author{
(See Page 41)
}

by Dr. SHIZUO YAMAMOTO, TAKASHI SEKI, NOBUAKI SUZUKI and SHOICHICHI

MATSUNAGA, Chiodo Construction Ltd. Co. Members of A.I.J. 